Does the adoption of AAOIFI affect corporate social responsibility

Dr/ Mona AL Hakim \& Dr/ Sherif Al Halaby

\title{
Does the adoption of AAOIFI affect corporate social responsibility disclosure? Evidence from
}

\author{
Islamic banks
}

\section{Mona AL Hakim-AOU University}

\section{Sherif Al Halaby-AOU University}

\section{Abstract}

In this study, we have investigated the impact of the implementation of AAOIFI (Accounting and Auditing Organization of Islamic Financial Institutions) on the level of corporate social responsibility disclosures (CSRD) within the context of Islamic banks. We measured the level of CSRD in annual reports using a disclosure instrument based on AAOIFI governance standard and other indexes from the previous studies. We have used data of 36 Islamic banks that was located in the Gulf Cooperation Council (GCC) between 2012 and 2016. We found out that AAOIFI adoption had a positive effect on CSRD. Furthermore, this paper - is the first one that has investigated to what extent adoption of financial accounting standards as AAOIFI can enhance the level of CSRD in Islamic banks. We contributed for the debate and literature about the economic consequences of adoption financial accounting standards specifically for Islamic standards. 
Does the adoption of AAOIFI affect corporate social responsibility

Dr/ Mona AL Hakim \& Dr/ Sherif Al Halaby

Key Words - Corporate Social Responsibility Disclosures;

AAOIFI; Islamic Banks; Gulf Cooperation Council

\section{Introduction}

This year marks the 27th anniversary since the Accounting and Auditing Organization of Islamic Financial Institutions (AAOIFI) established and issued Islamic accounting; governance and Sharia Standards for all Islamic financial institutions (IFIs). AAOIFI accounting standards serve as a guideline that may reflect the unique characteristics of IFIs and become a useful tool to meet the various needs of IFIs and the needs of its stakeholders (Sarea and Hanefah, 2013). One of its greatest successes has been its global adoption, with tens of hundreds of banks in over 25 countries currently reporting under, or at least closely linking their local accounting standards to, AAOIFI with more than 500 members (AAOIFI, 2017). Over the previous decade; Islamic world has been moving toward adoption of AAOIFI there has also been an increase interest in corporate social Responsibility (CSR), traditionally defined as the information provided on the effects of the firm's operations on employees, suppliers, customers and communities (McVea \& Freeman, 2005; Spence \& Gray, 2007) in addition to ethics, Sharia as Qard Hassan (Loan with free rate) related to IFIs. 
Does the adoption of AAOIFI affect corporate social responsibility

Dr/ Mona AL Hakim \& Dr/ Sherif Al Halaby

IBs are expected to perform the role of redistributing wealth to selective investments that contributed to the improvement and well-being of society (Farook, 2008). This IBs practiced the 'moral economy' philosophy expounded for religious or secular ethical reasons and support the inclusion of social and environmental aims in their investment policies (Belal et al., 2014). IBs should strive to achieve a balance between providing sufficient returns to their shareholders and social responsibilities and commitments to their various stakeholders (Ahmad, 2000). Concerning their social role, IBs are expected to bring economic and social benefits to their stakeholders; and to fulfill their CSR including its disclosure. Farook (2008) argued that disclosure provides evidence of the IBs involvement in social activities and hence earns legitimacy for their existence. IFIs may not be disclosing their social responsibility publicly, even though they are carrying out these activities. Therefore, to encourage disclosure, the international regulatory authorities as AAOIFI developed reporting standards for Islamic banks. In particular, it issued Standard No.7 on Governance Standards in relation to CSR conduct and disclosure in 2010. In the Standard, CSR for IFIs is defined as "all activities carried out by an IFI to fulfillers religious, economic, legal, ethical and discretionary responsibilities as financial intermediaries for individuals and institutions". 
Does the adoption of AAOIFI affect corporate social responsibility

Dr/ Mona AL Hakim \& Dr/ Sherif Al Halaby

The increasing interest in CSRD reporting and the move to AAOIFI affect the disclosure demands that IBs face. There is limited empirical evidence on the relationship between firms' disclosure practices and mandatory disclosure requirements by financial standards as AAOIFI. Adding to the literature in this area we attempted to comprehend how firms' CSR policies and level of disclosure are affected by the mandatory or voluntary disclosure requirements of AAOIFI. Ahmad (2004) provided empirical evidence that Islamic financial system is gradually and firmly becoming acceptable beyond political, geographical, and religious boundaries. Therefore, Islamic perspectives of accounting standard, disclosure, and corporate social reporting began to receive substantial attention, especially in the area of Islamic banking and finance. The study of Islamic accounting standards has grown in recent years with substantive contributions from scholars such as Baydoun \& Willet (1997), Gambling \& Karim (1986) and Lewis \& Algaoud (2001). It was notable; , that the focus of most of these studies was descriptive or analytical in nature, emphasizing specially on, the implications of Islam for accounting principles and practices, and the theoretical framework from which accounting standards for Islamic entities could potentially be derived (Baydoun \& Willett, 2000; Lewis, 2001). There was little recognition that a practical response to the impacts of adopting Islamic standards as 
Does the adoption of AAOIFI affect corporate social responsibility

Dr/ Mona AL Hakim \& Dr/ Sherif Al Halaby

AAOIFIwith the possibility of growing adoption of AAOIFI imminent for the majority of IFIs, this seems a suitable chance to investigate the effects of AAOIFI on various issues. Several researchers have approached this topic from several different perspectives but based on IFRS or GAAP standards, e.g., IFRS's impact on earnings management; the relationship between IFRS and information asymmetry (Leuz, 2003); how IFRS affects the cost of equity capital (Lambert et al., 2007); whether IFRS improves market liquidity and how IFRS affects Tobin's q, which measures effects beyond the cost of capital and market liquidity (Daske et al., 2008).

This study was motivated by different points. First; the statistics approved that; out of 500 IFIs around the world; just only less than 100 (20\%) apply AAOIFI. Through which we have investigated the positive consequences for applying these standards; we have also motivate other IFIs to adopt these kinds of standards. Second; there was a huge works related to investigate the outcomes of adopting IFRS and GAAP and approve different results (e.g., Evans et al., 2015; Barth et al., 2012) with rare literature concerning the AAOIFI (e.g., Mohammed et al (2015)). We motivated by a number of papers arguing that there is a need under Islamic teachings for more 'allembracing criteria of social accountability and full disclosure' (Baydoun \& Willett, 2000; Gambling \& Karim, 1986; Pomeranz, 
Does the adoption of AAOIFI affect corporate social responsibility

Dr/ Mona AL Hakim \& Dr/ Sherif Al Halaby

2004; Lewis, 2001; Sulaiman \& Willett, 2001; Maali et al., 2006). Recently, the academic community has taken great interest in research on CSR (Huang \& Watson, 2015). A significant body of evidence across business research disciplines examined questions such as which types of firms were engaged in CSR, and how CSR shaped firm decisions and outcomes. Yet to our knowledge there is no recent, measuring the impacts of financial accounting standards on the CSR disclosure. "Since the 1960s, there has been a growing interest in the economic and social effects of accounting regulations, particularly accounting standards ... accounting standards setting bodies such as ASC and FASB, have been confronted with arguments that particular proposals for accounting, or existing standards, given rise to economic consequences" (Taylor and Turley, 1986). However; there was a very rare focus on economic consequences for Islamic accounting standards (AAOIFI). This was motivating to conduct this research.

We have evaluated the impact of adoption AAOIFI on corporate CSRD practices in a sample of 36 IBs in GCC. This empirical context was unique in that despite having developed relatively new market strategies associated with western economies as market diversification, economic deregulation, and reformation of economic life (Anderson, 2000). Corporations in GCC countries are generally considered to operate in an Arab-Islamic 
Does the adoption of AAOIFI affect corporate social responsibility

Dr/ Mona AL Hakim \& Dr/ Sherif Al Halaby

context that is often considered to be opaque in terms of disclosure practices. Notwithstanding this view, investors have become interested in stabilizing the capital markets in an ArabIslamic context that is the home to many international financial institutions, a center of regional trade, and is integrated into the global economic system with an extraordinary speed (Kamla \& Roberts, 2010).

This paper reveals different incremental contributions to the literature of AAOIFI; social and ethical reporting practices as well as IBs. Although there is no any empirical studies investigating the link between CSRD and accounting standards as AAOIFI in the banking sector, as far as we are aware, this is the first study to empirically investigate this relationship in IBs. This paper adds value for academic literature that measures the consequences of adopting financial standards as IFRS or GAAP based on two points. We have added a new accounting standard which is AAOIFI in this field; we have added the impact of adopting accounting standards on the disclosure level for other impacts of these standards. We contributed to a rapidly growing literature concerning the impacts of accounting standards based on several aspects of the financial reporting system, as earnings in formativeness (Landsman et al., 2011), earnings persistence (Atwood et al., 2011), cost of capital (Li, 2010), and analysts' forecast accuracy (Byard et al., 2011). To the best of our 
Does the adoption of AAOIFI affect corporate social responsibility

Dr/ Mona AL Hakim \& Dr/ Sherif Al Halaby

knowledge, this is the first study in AAOIFI literature that explores AAOIFI effects on CSR disclosure. Our findings suggested that a greater level about CSR activities for IBs, as imposed by AAOIFI adoption.

The importance of this study has been approved from the significance of four dimensions concerning the CSRD, AAOIFI, Islamic banking industry and GCC as a hub centre for Islamic banking in MENA area. CSRD plays an important role in society because it provides information in demonstrating the organization's ethical accountability to its stakeholders to aid them in their decision making (Hassan \& Harahap, 2010). The financial assets of the Islamic financial sector totaled US \$2.7 trillion in 2017 and grew $50 \%$ faster than the overall banking sector with an average annual growth of $17.6 \%$ from 2013 to 2016 (Young, 2017). Furthermore, Islamic bank assets are expected to reach US $\$ 3.4$ trillion by 2018 and US $\$ 6.5$ trillion by 2020 (IFSB, 2010). AAOIFI is representing a benchmark for disclosure practices for all IFIs generally and for CSRD specifically. Based on the analysis in this study; we found that, adopting an Islamic financial accounting standard (AAOIFI) is considered one of the main determinants behind enhancing level of disclosure about CSR. In terms of structure, section 2 outlines the AAOIFI history and the adoption; section $\mathbf{3}$ discusses the literature review and hypotheses development. The sample 
Does the adoption of AAOIFI affect corporate social responsibility

Dr/ Mona AL Hakim \& Dr/ Sherif Al Halaby

selection and research methodology are presented in sections 4 . Section 5 presents the results and discussion of the findings, whilst section $\mathbf{6}$ summarizes and concludes.

\section{AAOIFI' History; Objectives and Adoption}

AAOIFI is a standard setting body located in Bahrain and established in 1991 (Maurer, 2002). According to AAOIFI, it is the leading international not-for-profit organization primarily responsible for develop accounting and auditing 'thoughts relevant to Islamic institutions; prepare, promulgate, interpret, review and amend accounting and auditing standards for Islamic financial institutions (IFIs) and to carry out commissioning of research in the area of Islamic accounting and auditing' (AAOIFI, 2017). The organization claims that these objectives are carried out in 'accordance with the precepts of Islamic Sharia'. The objective of the standards is to increase market confidence in the activities of Islamic banks, render them comparable, and facilitate transfer of Islamic banking and finance practices across national and regulatory contexts (Maurer, 2002). AAOIFI's founders aimed to avoid inconsistencies between individual boards and help in developing new products (Lewis, 2001). Despite that for most IFIs; AAOIFI standards are not mandatory; the AAOIFI has been successful in promoting its standards to IFIs globally. Amongst its most remarkable achievements is the issuance of 94 standards, so far, in the areas 
Does the adoption of AAOIFI affect corporate social responsibility

Dr/ Mona AL Hakim \& Dr/ Sherif Al Halaby

of Sharia, accounting, auditing, ethics and governance. Its standards are adopted by central banks and regulatory authorities in a number of countries, either on a mandatory basis or as basis of guidelines. AAOIFI is supported by numbers of institutional members, including central banks, regulatory authorities, financial institutions, accounting and auditing firms, and legal firms, from over 45 countries. Its standards are currently followed by the leading IFIs across the world and have introduced a progressive degree of harmonization of international Islamic finance practices (AAOIFI, 2017).

AAOIFI Sharia standards have been made part of mandatory regulatory requirement in jurisdictions such as Bahrain, Oman, Pakistan, Sudan and Syria and Islamic Development Bank Group. AAOIFI Sharia standards have also been used as basis of national Sharia guidelines in jurisdictions such as Indonesia and Malaysia. In other jurisdictions including Brunei, Dubai International Financial Centre, France, Jordan, Kuwait, Lebanon, Saudi Arabia, Qatar, Financial Centre, South Africa and United Kingdom as well as in Africa, Central Asia and North America, AAOIFI Sharia standards have been used voluntarily as basis of internal guidelines by leading IFIs. AAOIFI accounting standards have been made part of mandatory regulatory requirement in jurisdictions such as Bahrain, Jordan, Oman, Qatar, Sudan, and Syria (AAOIFI, 2017). AAOIFI accounting 
Does the adoption of AAOIFI affect corporate social responsibility

Dr/ Mona AL Hakim \& Dr/ Sherif Al Halaby

standards have also been adopted by Islamic Development Bank Group. It has also been used as basis of national accounting standards in jurisdictions such as Indonesia, Pakistan, Brunei, Dubai International Financial Centre, Egypt, France, Kuwait, Lebanon, Malaysia, Saudi Arabia, South Africa, United Arab Emirates and United Kingdom as well as in Africa and Central Asia. It has been used voluntarily as basis of internal guidelines by leading IFIs. AAOIFI auditing, governance and ethics standards are not part of mandatory regulatory requirement for Islamic finance. Instead, these standards are used voluntarily by leading IFIs across all major Islamic finance jurisdictions (AAOIFI, 2017).

\section{Literature review and hypotheses development}

The previous studies related to Islamic financial standards (AAOIFI) can be divided into three broad strands. The first strand uses content analysis to measure compliance level with these standards (e.g., Vinnicombe, 2012; Ullah, 2013; Ahmed \& Khatun, 2013; Sarea \& Hanefah, 2013; Sarea, 2013; Nassr \& Abdu Samia, 2015). The second strand investigates the determinants of adoption of these standards (e.g., El-Halaby \& Hussainey, 2016). Finally; the third strand investigates the main consequences through adoption these standards. This third strand is in the early research stage as - to the best of our knowledge - 
Does the adoption of AAOIFI affect corporate social responsibility

Dr/ Mona AL Hakim \& Dr/ Sherif Al Halaby

there was no empirical paper exploring to what extent adoption AAOIFI had a positive impacts generally and impact on disclosure particularly and specially CSRD. From the view of the literature concerned with CSRD; it can also be divided into the same three strands that have been before-mentioned. The first one measures level of disclosure about CSR activities in IFIs (e.g., Maali et al., 2006; Ullah \& Jamali, 2010; Haniffa \& Hudaib, 2007; Hassan et al., 2011; Belal et al., 2014; Aribi \& Gao, 2012). The second strand investigates the determinants of CSRD (e.g., Farook et al., 2011; Farag et al., 2014). Finally; the third strand investigates the main consequences for CSRD (e.g., Farag et al., 2014). The second strand- to the best of our knowledge - did not measure the adopting of financial accounting standards as AAOIFI as a factor behind CSRD. However, the impact of adopting AAOIFI on the level of CSR has not yet been investigated empirically in Islamic banks. Our paper is motivated to bridge a perceived gap related to the third strand on the impact of AAOIFI and to the second strand of the determinants of CSRD. Although; there are many literatures measuring level of CSR in Islamic banks (e.g., Hassan \& Harahap, 2010; Haniffa \& Hudaib, 2004; Maali et al., 2006) but rare studies measure for what extent adopting Islamic standards (AAOIFI) may enhance this level of disclosure. 
Does the adoption of AAOIFI affect corporate social responsibility

Dr/ Mona AL Hakim \& Dr/ Sherif Al Halaby

\subsection{Previous research on CSR disclosure}

A number of previous studies have investigated the level of CSRD in IFIs. Maali et al (2006) investigated the extent of social activities disclosed by IBs. They found that the level of social disclosure by the sample banks was well below their benchmark index. They concluded that banks adopting AAOIFI standards tend to provide more disclosures than non-compliant banks. Haniffa \& Hudaib (2007) investigated the disclosure of information deemed crucial to Islamic ethics in business. Using content analysis to determine the extent of CSRD, they found a significant gap between the communicated and ideal ethical disclosure in the annual reports. They concluded that for IBs to remain competitive, they need to communicate more effectively to enhance their image and reputation in society. Hassan \& Harahap (2010) focused on the disclosure of social activities in the annual reports. They found a significant expectations gap in disclosure level, and surmised that CSR issues are not the main concern for most IBs. They concluded that some IBs pay scant attention to disclosing their social activities and thus argued for a standard on CSRD relevant to IFIs. Abdul Rahman et al (2010) examined the CSRD of a Malaysian Islamic bank. They found that the volume and quality of CSRD improved over the 14-year study period. Farook et al (2011) empirically analyzed the level of social disclosure in forty-seven Islamic banks'. They found 
Does the adoption of AAOIFI affect corporate social responsibility

Dr/ Mona AL Hakim \& Dr/ Sherif Al Halaby

substantial variation in CSRD and this variation is best explained by the presence of SSB. Aribi and Gao (2012) analyzed the narrative disclosures of CSR in 21 IFIs operating in the Gulf countries. They found that the main CSRD were contained in SSB reports with less disclosure in the annual reports on other Islamic based information such as Zakah, interest free loans and charitable donations. Belal et al (2014) divided ethical reporting requirements into particular reporting practices and universal reporting practices. They found an overall increase in both disclosures over the study period with a shift towards more universal disclosures after 2006. Farag et al (2014) analyzed CSRD in a sample of 90 Islamic banks across 13 countries. Islamic banks seem to show more commitment to the vision and mission, the board and top management, and the financial product/services dimensions, whilst least attention is paid to the environment dimension. IBs showed a considerable awareness of the mandatory disclosure recommendations of AAOIFI however, they pay less attention to the voluntary CSRD. The CSR literature on IBs is largely qualitative based studies that measure the volume of narrative CSRD against an ideal benchmark drawn from Sharia based CSR objectives and AAOIFI standards. They generally found an expectation gap between actual/communicated disclosures and ideal disclosures. However, the main limitations of these studies are their reliance on 
Does the adoption of AAOIFI affect corporate social responsibility

Dr/ Mona AL Hakim \& Dr/ Sherif Al Halaby

measuring the level of disclosure for CSR activities without measuring the main determinants behind this disclosure level.

\subsection{Consequences of adoption financial accounting standards}

Gaa (1988) believed that the role of the standard setter is to "act in the interest of users by evaluating the consequences to investors of actions in accordance with financial accounting standards" (p, 34). An espoused benefit of accounting standards as IFRS adoption for some jurisdictions is that financial reporting becomes more transparent because IFRS provides users with additional disclosure requirements and specifies measurement and recognition rules that directly impact the quality of accounting numbers (Daske, 2006). For example, Barth et al (2008) found that firms adopting IFRS engage in less earnings management, exhibit more timely loss recognition and provide more value relevance of earnings. In addition, IFRS adoption is likely to increase market liquidity, decrease the firms' cost of capital, and increase equity valuations (Daske et al., 2008). Studies have also shown IFRS can enhance analysts' information environment (Byard et al., 2011; Stecher \& Suijs, 2012). It was also noted that jurisdictional differences influence IFRS implementation, hence the quality of accounting numbers and the information available to markets (e.g., Ball, 2006; Liao et al., 2012). Among the advantages of the adoption of the convergent accounting practices are the high-quality standards of the 
Does the adoption of AAOIFI affect corporate social responsibility

Dr/ Mona AL Hakim \& Dr/ Sherif Al Halaby

information supply and the decreased investment risk and capital cost enabled by transparency, as shown by Martins \& Brasil (2008). Oliver \& Warsame (2016) provided empirical evidence that value relevance increases in IFRS adoption. These findings are consistent with those of Jermakowicz et al (2007) who investigated firms' adoption of IFRS and find incremental value relevance for firms that adopted either IFRS or US GAAP. Hevas et al (2013) investigated whether the adoption of IFRS affected tax-induced incentives for financial earnings management. IFRS adoption reduced book-tax conformity, thereby releasing financial income from tax implications. There was an empirical literature on IFRS adoption consequences (e.g., Brown, 2011; Houqe et al., 2012; Pope \& McLeay, 2011; Soderstrom \& Sun, 2007 ), to the best of our knowledge our study was the first attempt to add these consequences based on a different accounting standards which is AAOIFI through measuring its impact on CSRD.

\subsection{Impact of Financial accounting standards adoption on CSRD}

Emmanuel et al (2016) based on a holistic review for IFRS adoption' studies found that; the majority of early studies paint IFRS as bringing significant benefits to adopting firms and countries in terms of improved transparency. Hail et al (2010) reviewed IFRS studies to determine the implications of US firms 
Does the adoption of AAOIFI affect corporate social responsibility

Dr/ Mona AL Hakim \& Dr/ Sherif Al Halaby

potentially switching to IFRS. In particular, they have shown the positive effects of potential IFRS adoption by the US on reporting quality and transparency level. Pope \& McLeay (2011) reviewed the empirical IFRS studies emerging and discuss implementation of IFRS in the EU. They found a positive implication for adoption IFRS on disclosure level. This result was matching with (Evans et al., 2015; Barth et al., 2012) that showed positive impact of accounting standard on the level of disclosure. Marston \& Robson (1997) found that disclosure had increased overtime. They thought that the reasons for improving disclosure in the Indian firms include increased compliance with IFRS.

Smith et al (2014) investigated the impact of the implementation of IFRS on CSRD. It measured the level of CSRD in annual reports using a disclosure instrument based on the United Nations Conference on Trade and Development report. It revealed that Firms in the stakeholder countries did not have a significant change in the level of CSRD following the mandatory adoption of IFRS while firms from the shareholder countries experienced a significant increase over the same period resulting in shareholder countries providing an overall higher level of CSRD after IFRS adoption than stakeholder countries. These findings suggested that firms' reactions to the requirements of IFRS and the stakeholder pressure to provide additional CSRD are influenced 
Does the adoption of AAOIFI affect corporate social responsibility

Dr/ Mona AL Hakim \& Dr/ Sherif Al Halaby

by institutional environment. Muller et al (2011) evaluated the effects of the increased disclosure of fair values required under IFRS on the degree of information asymmetry faced by investors. Using a sample of European real estate firms, they discovered that firms that did not voluntarily disclose fair values before mandatory IFRS adoption experienced larger improvements in information asymmetry, i.e., larger declines in their bid-ask spreads, upon IFRS adoption. Christensen (2012); Daske et al (2013) discovered that the change in disclosure incentives for adopting firms drives the documented capital market benefits following voluntary IFRS adoption. Oliveira \& Lemes (2011) analyzed the financial statements to evaluate the adaptation level to IFRS of the information disclosed in the Brazilian and NorthAmerican markets. They suggested that the Brazilian financial statements tend to substantially be modified, increasing the disclosure level. Empirical studies confirmed that disclosure quality tends to improve for European firms after the adoption of IFRS rules (Daske \& Gebhardt, 2006).

Based on context of IFIs; Mohammed et al (2015) measured the issue relevant to the need for Islamic accounting standards in reporting IFIs, in the context of Malaysia. With recent rapid growth of IFIs, there was still inconclusive stance regarding the need for specificity accounting standards for IFIs such as the ones issued by AAOIFI. The study offered evidence on the 
Does the adoption of AAOIFI affect corporate social responsibility

Dr/ Mona AL Hakim \& Dr/ Sherif Al Halaby

influence of AAOIFI accounting standards in reporting IFIs. The all previous studies focused on adopting IFRS based on context of EU and USA. While the rare studies that focused on IFIs or even developed country as Malaysia using qualitative methods based on interviews; it investigated the impacts of adoption AAOIFI on reporting generally without study impact on disclosure level as indicated in this paper. This would ask future research about developing countries as well as Islamic standards as AAOIFI. Moreover, it would contribute for academic research concerned with consequences of adopting accounting standards on the CSRD level. We based our prediction on the increased disclosure quality after the adoption of financial accounting standards rules (Daske \& Gebhardt, 2006). Indeed, the increased level of disclosure required by the new standards with more information to better understand and evaluate a company's accounting policies and reports. In other words, we believed that the higher quality and transparency of the AAOIFI rules will enhance the disclosure level about CSR activities. Therefore, we formulated the following hypotheses

H. There is a positive association between adopting of AAOIFI and level of CSRD

\section{Methodology}

Our dataset was a cross-sectional analysis of the relationship between CSR disclosure and adoption AAOIFI by Islamic banks 
Does the adoption of AAOIFI affect corporate social responsibility

Dr/ Mona AL Hakim \& Dr/ Sherif Al Halaby

over the period 2012-2016. We used Bank-scope, Zawya and Bankers databases for the sample selection. From 200 Islamic banks with $100 \%$ Sharia compliant assets around the world; we collected data for 36 Islamic banks that located in Gulf Cooperation Council (GCC) area namely Bahrain, Kuwait, Qatar, Saudi Arabia (KSA), United Arab Emirates (UAE) and Oman. The dataset was hand collected from the annual reports and the websites of the respective banks. Data were collected from Bankscope, the Banker database, and Zawya database, in addition to the annual reports and websites. Financial information was collected from Thomson One Banker and Bank-scope.

\subsection{CSRD measurement}

CSRD was measured using a content analysis technique. Content analysis is a method of codifying text into groups or categories thus allowing the material to be transformed into quantitative scales that permit further analysis. Content analysis has been widely used by researchers trying to obtain reliable and valid information from texts (Boesso \& Kumar, 2007). The importance of using this methodology for understanding stakeholder reporting practices was emphasized by Guthrie et al (2004). CSRD data was collected from the banks' annual reports of 2012, 2013, 2014, 2015 and 2016. The annual report is recognized as a primary method of communicating with financial and nonfinancial stakeholders (Neu et al., 1998) as evidenced by research 
Does the adoption of AAOIFI affect corporate social responsibility

Dr/ Mona AL Hakim \& Dr/ Sherif Al Halaby

observing variations in the quality and level of CSD in annual reports (Boesso \& Kumar, 2007; Van der Laan Smith et al., 2005).We argued that corporate reporting through the annual report provided a vehicle for examining shifting stakeholder relationships through the choices managers make in the information they disclose. It was a proxy for the stakeholder pressures perceived by company managers. We believed that this argument is consistent with the theoretical origins of stakeholder management which strives to integrate the management of economic and social objectives (Harrison \& Freeman, 1999).

Our dependent variable is the CSR index. The CSR disclosure index incorporates items from Maali et al (2006); Haniffa and Hudaib (2007); Farag et al (2014) and El-Halaby and Hussainey (2016) studies. We reclassified the index items into two categories namely universal oriented CSR and Sharia oriented CSR aspects based on Belal et al (2014). The first category consisted of CSR items generally expected in conventional banks. The second category consisted of CSR items relating purely to Sharia principles. The index consisted of 14 dimensions. Our checklist consisted of 95 items and we checked each item across the 36 annual reports and then we dealt with each item as a dummy variable which takes value of one if the item was found in the annual reports/websites and zero otherwise. Our index is equally 
Does the adoption of AAOIFI affect corporate social responsibility

Dr/ Mona AL Hakim \& Dr/ Sherif Al Halaby

weighted to avoid any potential scoring and scaling biases following Haniffa \& Hudaib (2007) as shown in Eq. (1).

$$
\operatorname{CSRI}_{i}=\frac{\sum_{t=1}^{n} X_{i}}{n}
$$

Where $C S R I_{i}$ is corporate social disclosure index $0 \leq C S R I_{i} \leq 1, n_{i}$ is the number of items expected for bank $\mathrm{I} \mathrm{n} \leq 95$ and $X_{i}$ is a dummy variable which takes the value of 1 if the item is disclosed and 0 otherwise. We took precautionary measures to enhance the validity and the reliability of our analysis. We checked that the index items generated from the classification procedures represented what we intended to represent. The authors examined the items of the index and decided that specific item was intended to measure (Beattie et al., 2004). In addition, we made sure that each item and the overall index are closely related to CSR in Islamic banks as we have carefully chose and developed the 14 dimensions of our CSR index based on the previous literature and the CSR Conduct and Disclosure for IFIs issued by AAOIFI. To enhance the reliability, the index items are coded and checked three times and we discussed any potential discrepancies. It is worth mentioning that each bank is coded by two different authors to ensure consistency. We made sure that the same coder is consistent overtime when coding the same item 
Does the adoption of AAOIFI affect corporate social responsibility

Dr/ Mona AL Hakim \& Dr/ Sherif Al Halaby

of the index (stability), the coders produce the same results when coding the same item (reproducibility) and accuracy as well.

\begin{tabular}{|c|c|c|}
\hline Social disclosure index & Items and corresponding AAOIFI standard & Items \\
\hline & Universal-oriented CSR disclosure & \\
\hline & Employee welfare & 12 \\
\hline & Internal environment preservation policy & 9 \\
\hline & Par excellence customers services & 5 \\
\hline & $\begin{array}{l}\text { Micro and small business and social saving } \\
\text { and investments and development }\end{array}$ & 10 \\
\hline & Charitable activates & 6 \\
\hline & Social responsibility & 13 \\
\hline & Sharia-oriented CSR disclosure & \\
\hline & Late repayments and insolvent clients & 10 \\
\hline & Qard Hassan & 10 \\
\hline & Zakat & 7 \\
\hline & Waqf management & 5 \\
\hline & Earning and expenditure prohibited by Sharia & 4 \\
\hline & $\begin{array}{l}\text { Screening and informing clients for } \\
\text { compliance with Sharia }\end{array}$ & 4 \\
\hline & Average compliance level & 95 \\
\hline
\end{tabular}

\subsection{Independent Variables}

We measured our main independent variable which is adoption accounting standards as a dummy variable based on 1 if the bank adopts AAOIFI and 0 otherwise. We control for firm characteristics; corporate governance (Universal and Sharia) and country variables. We used Board size to capture the effect of board structure on CSR disclosure. Academicians find a significant positive relationship between board size and CSRD (Javaid Lone et al., 2016, Majeed et al., 2015, Alotaibi \& Hussainey, 2016, Barakat et al., 2015, Samaha et al., 2012). 
Does the adoption of AAOIFI affect corporate social responsibility

Dr/ Mona AL Hakim \& Dr/ Sherif Al Halaby

Return on assets (ROA) is widely used measure of financial performance (FP). Roberts (1992) argued that a level of FP has a direct impact on the decisions by the board of directors and their commitment to future CSR activities and expenditures. We expected an association between CSR and FP (e.g., Mallin \& Michelon, 2011). Moreover, we used the natural logarithm of total assets as a proxy for bank size; it was argued that the bank size has an impact on the level of corporate social activities. A large strand of the literature on CSR discovered an association between size and CSR activities (e.g., Brammer et al., 2006; Amranet al., 2009).

SSB had social influence and authority in monitoring IB's compliance with Sharia principles, and provided the confidence to stakeholders about the legitimacy of the business transactions. Disclosure by SSB may be seen as a key aspect of accountability by IB to its stakeholders. Moreover, the degree to which the SSB influenced the level of CSRD may depend on characteristics as Sharia board size; Sharia board reputation (based on its membership in credible Islamic institutions) and experiences and credibility (based on its membership in more than one IB). An increase in the number of SSB members may lead also to higher levels of CSRD as the capacity for monitoring increases. The greater number of members in SSB, the greater the amount of monitoring, implying a greater level of compliance with 
Does the adoption of AAOIFI affect corporate social responsibility

Dr/ Mona AL Hakim \& Dr/ Sherif Al Halaby

Islamic laws and principles. SSB would be able to allocate its functions across a larger group of members, allowing the SSB to review more aspects of the banks' activities and hence ensure greater compliance. Therefore, Sharia board size was expected to have a positive impact on CSRD (Farook et al., 2011; Farag et al., 2014). The governance literature indicated the level of disclosures that could increase or decrease depending on whether mechanisms substitute or complement each other (Ho \& Wong, 2001). If the governance mechanisms were complementary as in Islamic banking (BOD and $\mathrm{SSB}^{1}$ ), agency theory suggested that a higher level of disclosures was expected as more governance mechanisms will strengthen the monitoring aspect leading to a reduction in information asymmetry and opportunistic behavior. SSB in its role as an additional governance body would pressure IBs to disclose more CSR activities in order to assure its investors that it is following Sharia laws.

Cross-memberships of SSB members may also lead to higher disclosure of CSR information (Dahya et al., 1996). The

${ }^{1}$ It was expected that Sharia board acts as a complementary mechanism because compliance with Islamic laws and principles should not only be generally inferred within the Sharia report but also reinforced with disclosures of specific CSR activities. Hence, it was generally expected that SSB in an IB would lead to higher disclosure levels of CSR activities (Farag et al., 2014). 
Does the adoption of AAOIFI affect corporate social responsibility

Dr/ Mona AL Hakim \& Dr/ Sherif Al Halaby

literature suggested that cross-directorships increase transparency as members with cross-directorships can make comparisons from knowledge gained in other firms (Haniffa \& Cooke, 2002). Hussain \& Mallin (2003) argued that, the factors influencing the appointment of directors in firms are relevant skills, business experience and reputation. It was expected that reputation is a proxy for industry knowledge and hence reputable scholars with relevant degrees in Sharia and business and who were represented in many IFIs Sharia boards, were more likely to understand current implications of Islamic banking, particularly with regards to disclosure. Hence, reputable scholars were more likely to emphasize CSR activities and the subsequent disclosure of CSR information.

We controlled also board meeting. There was a positive association between frequency of board meetings and disclosure quality (Anis et al., 2012). The numerous board meeting enabled to give more attention on social related matters (Giannarakis, 2014a). We controlled variables related to audit committee (based on existing this committee and its size). We also control for the macro-economic factors by using the Worldwide Governance Indicators for countries. These indicators included Voice and Accountability; Regulatory Quality; Rule of Law and Control of Corruption. In addition, we used leverage (the ratio of total debts/total assets) to control for the differences in IBs 
Does the adoption of AAOIFI affect corporate social responsibility

Dr/ Mona AL Hakim \& Dr/ Sherif Al Halaby

operating business efficiency (Andres \& Vallelado, 2008). Firms with higher levels of debt typically worked to reduce information asymmetry by disclosing more information to their stakeholders (e.g. Abraham \& Cox, 2007; Holthausen, 1990; Iatridis, 2008; Linsley \& Shrives, 2006; Lopes \& Rodrigues, 2007). We used as well Tier 1 capital expressed as a percentage of total risk weighted assets to control for IBs risk (Farag et al., 2014). Finally, country dummies as well as year dummies are used to capture country and year heterogeneity and to control for country and years specific effects.

\subsection{Research model}

To empirically investigate the relationship between CSRD and adoption AAOIFI in Islamic banks, we use the following OLS regression as in Equation (2):

$\operatorname{CSRDI}_{i t}=\beta 0+\beta 1$ STAND $_{i t}+\beta 2$ B.SIZE $E_{i t}+\beta 3$ B. MEET $_{i t}$ $+\beta 4 S S B . S I Z E_{i t}+\beta 5$

SSB. $R_{i t}+\beta 6 S S B . C M_{i t}+\beta 7$

AC. $E_{i t}+\beta 8$ AC.SIZE $E_{i t}+\beta 9$ VOICE $_{i t}+\beta 10$ REGUL $_{i t}+$

$\beta 11 \mathrm{LAW}_{i t}+\beta 12 \mathrm{CORR}_{i t}+\beta 13$ SIZE $_{i t}+\beta 14 \mathrm{ROA}_{i t}+\beta 15$

$L E V_{i t}+\beta 16 C A P_{i t}+$

$\beta 17$ CON.DUM $M_{i t}+\beta 18$ YEA.DUM $M_{i t}+\varepsilon_{i t}$

Where: Variable definition: CSRDI $=$ Corporate Social Responsibility disclosure index for bank i; SIZE = natural logarithm of total assets; STAND=dummy code 1 if the banks 
Does the adoption of AAOIFI affect corporate social responsibility

Dr/ Mona AL Hakim \& Dr/ Sherif Al Halaby

adopt AAOIFI/other Islamic standards or 0 otherwise; LEV= leverage ratio based on total liabilities for total assets; $\mathbf{R O A}=$ profitability (return on assets); $\mathbf{C A P}=$ ratio of actual regulatory capital (Tier 1 capital) to the minimum required regulatory capital; B.SIZE $=$ total number board members; B.MEET $=$ number of BOD meeting within the year; SBB.SIZE= the number of Sharia supervisory board members for bank; SSB.R = dummy code 1 if the SSBM are has membership in a credible Islamic institutions as AAOIFI or 0 otherwise; SSB.CM= dummy code 1 if SSB member with a cross membership in more than one Islamic bank or 0 otherwise; AC.E = dummy code (audit committee exist) 1 if there is audit Committee inside the Islamic banks or 0 otherwise; AC.SIZE= total number of audit committee; The Worldwide Governance Indicators: VOICE $=$ Voice and Accountability; REGUL= Regulatory Quality; LAW= Rule of Law; CORR= Control of Corruption; and $\mathbf{\varepsilon i}$ are the white noise error terms associated with the unobservable effects resulting from firm heterogeneity i.e. unobservable features of managerial behavior that explain heterogeneity in CSRD and adoption of AAOIFI.

\section{Results and Discussion}

Table 1 provides the descriptive statistics for the dependent, independent and control variables. The sample size is 36 Islamic banks and the average CSR disclosure index ranges from $12 \%$ to 
Does the adoption of AAOIFI affect corporate social responsibility

Dr/ Mona AL Hakim \& Dr/ Sherif Al Halaby

$50 \%$ with an average of $30 \%$. Of the 36 Islamic banks in the study, 66.6\% are adopted AAOIFI and 33.3\% adopted other standards such as IFRS and Local standards. The average return on assets (ROA) ranges from $-45.31 \%$ to $31.95 \%$ with a mean of $-0.57 \%$. Table 3 also reports that average board size for our Islamic banks is 9 members and they meet 5 times annually. 77\% from SSB have membership in AAOIFI committees as well as $87.5 \%$ from these members are serving in other Islamic banks. The table reports that SSB size ranges from 3 to 9 members with mean value of 3.64 . 82\% from our selected banks have audit committee and each committee have an average 3 members. $82 \%$ from our selected banks has an audit committee with average 2.5 members in each bank. Finally, the average natural logarithm of bank size is US\$ 3.15 million. Table 6 reports the outputs of the correlation matrix of the covariates used in the analysis. It is clear that there are no significant correlation coefficients greater than $50 \%$, therefore our estimation is not subject to multicollinearity problem $^{2}$.

\footnotetext{
${ }^{2}$ It should also be noted that multicollinearity between the variables did not appear to be a problem for the following reasons. First, as can be seen from Table 2, the highest correlation (Pearson or Spearman rank) between any of the independent/control variables was only 0.594. Second, the standardized residuals from the OLS regression analysis appeared to be normally distributed (Kolmogorov-Smirnov $Z=0.563 ; p=0.921$ ). Third, the highest VIF value was 6.975 as presented in table 3 (Wu and Tu, 2007)
} 
Does the adoption of AAOIFI affect corporate social responsibility

Dr/ Mona AL Hakim \& Dr/ Sherif Al Halaby

Table 1: Descriptive Statistics

\begin{tabular}{|l|c|c|c|c|c|c|}
\hline & Minimum & Maximum & Mean & Std. Dev & Skewness & Kurtosis \\
\hline CSRD & 0.12 & 0.50 & $\mathbf{0 . 3 0 3 2}$ & 0.1167 & -1.122 & 1.228 \\
\hline STAND & 0.00 & 1.00 & $\mathbf{0 . 6 6 6 7}$ & 0.4727 & -0.713 & -1.508 \\
\hline SIZE & 2.25 & 4.91 & $\mathbf{3 . 1 5 4 3}$ & 1.0629 & -1.162 & 1.512 \\
\hline LEV & 34.00 & 99.27 & $\mathbf{4 1 . 6 3 7 1}$ & 35.3209 & 0.618 & -1.426 \\
\hline ROA & -45.31 & 31.95 & $\mathbf{- 0 . 5 7 6 5}$ & 8.9779 & -1.544 & 9.315 \\
\hline CAP & 45.22 & 137.76 & $\mathbf{2 6 . 6 3 4 0}$ & 24.961 & 2.265 & 5.386 \\
\hline B.SIZE & 6.00 & 16.00 & $\mathbf{8 . 6 7 8 6}$ & 2.6369 & -1.209 & 3.420 \\
\hline B.MEET & 5.00 & 14.00 & $\mathbf{5 . 3 1 0 1}$ & 2.0900 & 0.365 & 2.847 \\
\hline SSB.R & 0.00 & 1.00 & $\mathbf{0 . 7 7 2 4}$ & 0.4207 & -1.313 & -0.280 \\
\hline SSB.CM & 0.00 & 1.00 & $\mathbf{0 . 8 7 5 9}$ & 0.3308 & -2.304 & 3.353 \\
\hline SSB.SIZE & 3.00 & 9.00 & $\mathbf{3 . 6 4 8 1}$ & 1.3580 & 0.180 & 1.815 \\
\hline AC.E & 0.00 & 1.00 & $\mathbf{0 . 8 2 9 6}$ & 0.3773 & -1.773 & 1.162 \\
\hline AC.SIZE & 3.00 & 5.00 & $\mathbf{2 . 5 4 0 7}$ & 1.4443 & -0.648 & -0.675 \\
\hline VOICE & -1.86 & -0.51 & $\mathbf{- 1 . 1 7 8 3}$ & 0.3746 & -0.364 & -0.718 \\
\hline REGUL & -0.13 & 0.98 & $\mathbf{0 . 4 6 0 3}$ & 0.3169 & -0.562 & -1.208 \\
\hline LAW & 0.05 & 1.04 & $\mathbf{0 . 4 6 7 3}$ & 0.2430 & 1.031 & 0.345 \\
\hline CORR & -0.37 & 1.57 & $\mathbf{0 . 4 3 4 8}$ & 0.4819 & 0.754 & -0.458 \\
\hline Varb & & CSRD & 0.9619 &
\end{tabular}

Variable definition: $\mathbf{C S R D}=$ Corporate Social Responsibility disclosure; SIZE $=$ natural logarithm of total assets; STAND=dummy code 1 if the banks adopt AAOIFI/other Islamic standards or 0 otherwise; $\mathbf{L E V}=$ leverage ratio based on total liabilities for total assets; $\mathbf{R O A}=$ profitability (return on assets); $\mathbf{C A P}=$ ratio of actual regulatory capital (Tier 1 capital) to the minimum required regulatory capital; B.SIZE $=$ total number board members; B.MEET $=$ number of BOD meeting within the year; SBB.SIZE= total number of SSBM on the board; SSB.R= dummy code 1 if the SSBM are has membership in a credible Islamic institutions as AAOIFI or 0 otherwise; SSB.CM= dummy code 1 if SSB member with a cross membership in more than one Islamic bank or 0 otherwise; $\mathbf{A C . E}=$ dummy code (audit committee exist) 1 if there is audit Committee inside the Islamic banks or 0 otherwise; AC.SIZE = total number of audit committee; The Worldwide Governance Indicators: VOICE $=$ Voice and Accountability; REGUL= Regulatory Quality; LAW= Rule of Law; CORR= Control of Corruption 
Does the adoption of AAOIFI affect corporate social responsibility

Dr/ Mona AL Hakim \& Dr/ Sherif Al Halaby

Table 2: Pearson and Spearman rank correlation coefficients matrix

\begin{tabular}{|c|c|c|c|c|c|c|c|c|c|c|c|c|c|c|c|c|c|}
\hline & CSRD & \begin{tabular}{|l|} 
SIZE \\
\end{tabular} & STAND & LEV & ROA & CAP & \begin{tabular}{|c|} 
B.SIZE \\
\end{tabular} & B.MEET & 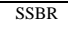 & SSB.CM & SSB.SIZE & $\mathrm{AC}$ & ACSIZE & VOICE & REGUL & LAW & CORR \\
\hline \multicolumn{18}{|c|}{ Pearson correlation coefficients } \\
\hline CSRD & 1.000 & $0.305^{\prime \prime}$ & 0.258 & 0.038 & -0.027 & 0.152 & $0.501 "$ & $0.480^{\prime \prime \prime}$ & $0.259^{\prime \prime \prime}$ & $0.354^{* \prime \prime}$ & $0.342^{* \prime}$ & 0.066 & -0.033 & $-0.290^{\prime \prime \prime}$ & 0.039 & $-0.225^{\prime \prime \prime}$ & -0.095 \\
\hline SIZE & & 1.000 & $-0.391^{\prime \prime}$ & $-0.521^{1 *}$ & $0.215^{\circ}$ & $-0.234^{\circ}$ & $0.494^{\circ *}$ & $0.532^{\prime \prime}$ & 0.104 & $0.320^{\prime \prime}$ & $0.353^{* \prime}$ & 0.148 & 0.159 & $0.209^{\circ}$ & 0.046 & $0.295^{517}$ & $0.517^{* *}$ \\
\hline STAND & & & 1.000 & $0.430^{\prime \prime}$ & -0.091 & $0.273^{\prime \prime}$ & 0.017 & -0.045 & $0.298^{\prime \prime}$ & 0.167 & -0.298 & 0.048 & -0.121 & -0.097 & $0.490^{\prime \prime}$ & 0.206 & 0.112 \\
\hline LEV & & & & 1.000 & -0.168 & $0.563^{* \prime \prime}$ & $-0.248^{\circ}$ & $-0.473^{* \prime}$ & 0.041 & $-0.271^{1 *}$ & $-0.328^{\circ *}$ & -0.172 & -0.203 & $-0.214^{\circ}$ & 0.000 & $-0.348^{*}$ & $-0.529^{* \prime}$ \\
\hline ROA & & & & & 1.000 & 0.334 & 0.190 & $0.209^{\prime}$ & 0.098 & 0.181 & 0.110 & $-0.253^{\prime \prime}$ & -0.075 & -0.033 & 0.015 & 0.072 & $0.203^{\circ}$ \\
\hline CAP & & & & & & 1.000 & 0.068 & 0.033 & 0.182 & 0.102 & -0.120 & -0.406 & $-0.395^{\prime \prime}$ & -0.018 & 0.173 & -0.076 & -0.100 \\
\hline B.SIZE & & & & & & & 1.000 & $0.466^{\prime \prime 2}$ & $0.364^{* 1 "}$ & $0.346^{6 *}$ & $0.492^{\circ *}$ & $0.191^{\circ}$ & $0.255^{*}$ & $-0.252^{\circ "}$ & 0.009 & -0.117 & 0.008 \\
\hline B.MEET & & & & & & & & 1.000 & 0.143 & $0.256 "$ & $0.323^{\prime \prime}$ & 0.095 & -0.002 & -0.015 & 0.005 & 0.087 & $0.161^{\circ}$ \\
\hline $\begin{array}{lll}\text { SSB.R } \\
\end{array}$ & & & & & & & & & 1.000 & 0.594 & $0.234 "$ & 0.315 & $0.175^{\circ}$ & -0.152 & 0.123 & 0.023 & 0.052 \\
\hline SSB.CM & & & & & & & & & & 1.000 & $0.164^{\circ}$ & 0.066 & -0.100 & -0.098 & $0.303^{\prime \prime}$ & 0.058 & $0.321^{\prime \prime}$ \\
\hline SSB.SIZE & & & & & & & & & & & 1.000 & 0.069 & $0.230^{* *}$ & $-0.288^{* 14}$ & $-0.319^{* 17}$ & $-0.339^{* \prime}$ & $-0.244^{* \prime \prime}$ \\
\hline AC.E & & & & & & & & & & & & 1.000 & $0.500^{\prime \prime}$ & -0.070 & 0.035 & 0.073 & -0.015 \\
\hline AC.SIZE & & & & & & & & & & & & & 1.000 & $-0.288^{* 17}$ & $-0.187^{\circ}$ & -0.075 & -0.087 \\
\hline VOICE & & & & & & & & & & & & & & 1.000 & $0.276^{60}$ & $0.454^{\circ "}$ & $0.370^{\circ "}$ \\
\hline REGUL & & & & & & & & & & & & & & & 1.000 & 0.463 & $0.583^{\prime \prime}$ \\
\hline LAW & & & & & & & & & & & & & & & & 1.000 & $0.494^{\prime \prime}$ \\
\hline CORR & & & & & & & & & & & & & & & & & 1.000 \\
\hline \multicolumn{18}{|c|}{ Spearman rank correlation coefficients } \\
\hline CSRD & 1.000 & -0.070 & 0.406 & 0.107 & $-0.252^{\circ}$ & 0.103 & $0.268^{\prime \prime}$ & $0.277^{*}$ & $0.188^{\circ}$ & $0.230^{\circ \prime \prime}$ & $0.173^{\circ}$ & 0.076 & \begin{tabular}{|c|}
-0.042 \\
\end{tabular} & $-0.366^{\circ 10}$ & \begin{tabular}{ll|}
0.064 \\
\end{tabular} & $-0.324^{*}$ & -0.114 \\
\hline $\begin{array}{l}\text { SIZE } \\
\end{array}$ & & 1.000 & -.384 & -0.519 & $0.359^{\prime \prime}$ & -0.199 & $\begin{array}{ll}0.093 \\
\end{array}$ & $.359^{\prime \prime}$ & \begin{tabular}{c|}
-0.009 \\
\end{tabular} & $0.195^{\circ}$ & 0.103 & 0.071 & 0.038 & $0.395^{\prime \prime}$ & 0.096 & \begin{tabular}{|l|l|}
$0.370^{*}$ \\
\end{tabular} & $0.529^{\prime \prime}$ \\
\hline STAND & & & 1.000 & $.537^{\prime \prime}$ & 0.044 & $.220^{\circ}$ & 0.091 & $\begin{array}{c}-0.049 \\
\end{array}$ & .298 & 0.167 & $-0.333^{\prime \prime}$ & 0.048 & $\begin{array}{l}-0.142 \\
\end{array}$ & \begin{tabular}{|c|}
-0.131 \\
\end{tabular} & .424 & $.174^{\prime}$ & $.240^{\prime \prime}$ \\
\hline$\overline{\text { LEV }}$ & & & & 1.000 & 0.025 & $.575^{\prime \prime}$ & \begin{tabular}{c|}
-0.048 \\
\end{tabular} & -.512 & 0.128 & \begin{tabular}{|c|}
-0.193 \\
\end{tabular} & -0.347 & -0.084 & -0.170 & -0.182 & 0.039 & -0.154 & -.346 \\
\hline ROA & & & & & 1.000 & 0.170 & 0.020 & 0.097 & 0.146 & $0.255^{\prime \prime}$ & $\begin{array}{l}-0.173 \\
\end{array}$ & $\begin{array}{c}-0.079 \\
\end{array}$ & -0.032 & $.228^{\circ}$ & 0.134 & $.314^{* \prime \prime}$ & $.538^{\circ 17}$ \\
\hline CAP & & & & & & 1.000 & 0.127 & -0.018 & $.272^{\prime \prime \prime}$ & 0.164 & $-0.245^{\circ}$ & $-.259^{\circ}$ & $-.367^{\prime \prime}$ & 0.051 & 0.160 & 0.038 & 0.049 \\
\hline B.SIZE & & & & & & & 1.000 & $.307^{\prime \prime}$ & $251^{\circ "}$ & 0.136 & $0.404^{* n}$ & $.216^{\circ}$ & $.289^{\circ \prime}$ & $-.223^{* \prime}$ & 0.057 & $-.202^{\circ}$ & -0.038 \\
\hline B.MEET & & & & & & & & 1.000 & \begin{tabular}{c|}
-0.008 \\
\end{tabular} & 0.067 & $0.254^{\prime \prime \prime}$ & 0.045 & 0.017 & 0.002 & 0.028 & 0.015 & 0.097 \\
\hline \begin{tabular}{|l|l|} 
SSB.R \\
\end{tabular} & & & & & & & & & 1.000 & 0.594 & 0.116 & .315 & 0.137 & -0.125 & 0.155 & \begin{tabular}{|c|}
-0.078 \\
\end{tabular} & 0.101 \\
\hline SSB.CM & & & & & & & & & & 1.000 & 0.027 & 0.066 & -0.133 & $\begin{array}{l}-0.083 \\
\end{array}$ & $.323^{\circ \prime}$ & 0.004 & $.364^{\circ \prime}$ \\
\hline SSB.SIZE & & & & & & & & & & & 1.000 & 0.014 & $.284^{-10}$ & $-209^{* \prime \prime}$ & $-.293^{\prime \prime}$ & $-.408^{\prime \prime \prime}$ & $-.324^{* m}$ \\
\hline AC.E & & & & & & & & & & & & 1.000 & $.591^{\prime \prime}$ & $\begin{array}{l}-0.039 \\
\end{array}$ & 0.072 & \begin{tabular}{c|}
-0.016 \\
\end{tabular} & -0.046 \\
\hline
\end{tabular}


Does the adoption of AAOIFI affect corporate social responsibility

Dr/ Mona AL Hakim \& Dr/ Sherif Al Halaby

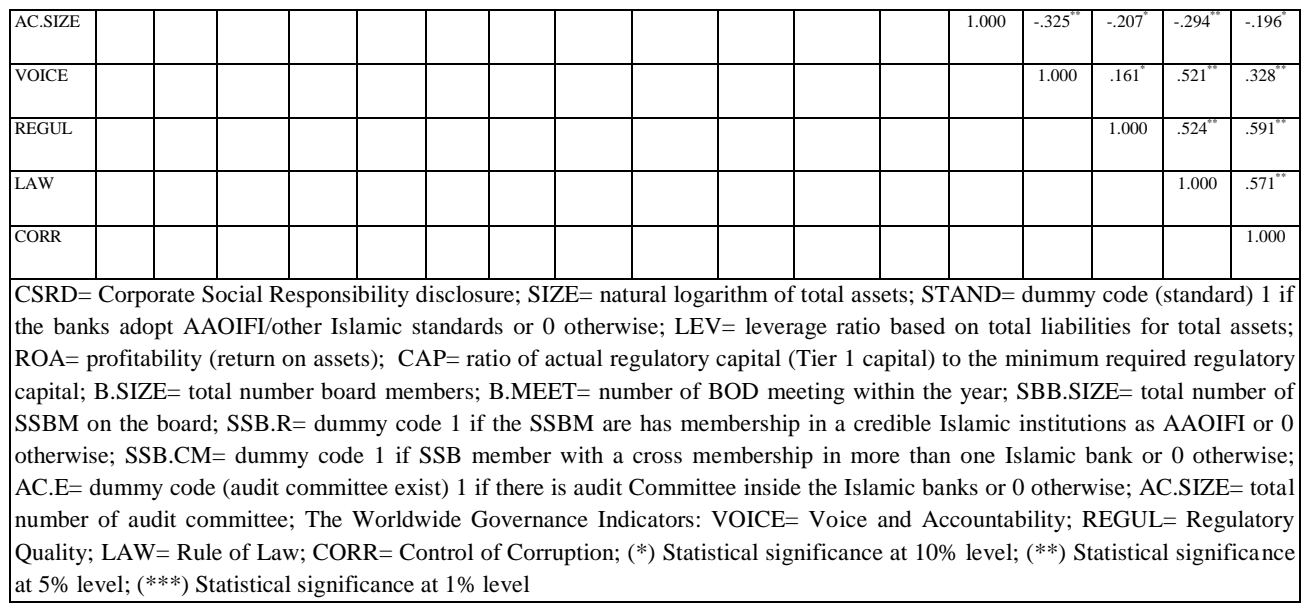

Table 3 reports the multivariate analysis of our CSRD model using linear regression. In support of our hypothesis, CSRD is significantly positively associated with accounting standards or AAOIFI. This result is matching with Maali et al. (2006) that concluded that banks adopting AAOIFI standards tend to provide more disclosures than non-compliant banks. Related to our control variables; the results indicate that CSRD level is significantly positively associated with size; corporate governance of board; AC as well as SSB. In terms of the worldwide governance indicators to control variances between countries, as unexpected, CSRD is significantly negatively associated only with Rule of Law. However, the results show no significant association between the level of CSRD and other indicators (Regulatory Quality; Control of Corruption and Voice 
Does the adoption of AAOIFI affect corporate social responsibility

Dr/ Mona AL Hakim \& Dr/ Sherif Al Halaby

and Accountability). Using various alternative proxies for the independent and control variables did not improve our results and, therefore, the findings for these alternative proxies are not presented. The level of explained variance in our study (The model shows that adjusted $\mathrm{R}$ square is $48.3 \%$ ) is higher than prior studies (e.g., Chan et al., 2013, were only able to explain $35 \%$ and Branco and Rodrigues 2008, were only able to explain $33.5 \%$ of the variance in their study of CSRD) which supported our results.

Table 3: Regression results

\begin{tabular}{|l|c|c|c|c|}
\hline \multicolumn{1}{|c|}{ Model } & Coeff & t.stat & Sig & VIF \\
\hline Constant & -0.078 & -1.190 & 0.236 & \\
\hline STAND & $\mathbf{0 . 1 1 1}$ & 5.367 & $\mathbf{0 . 0 0 0}$ & 2.409 \\
\hline Control Variables & & & & \\
\hline SIZE & $\mathbf{0 . 0 5 5}$ & 4.129 & $\mathbf{0 . 0 0 0}$ & 3.890 \\
\hline ROA & 0.001 & 1.289 & 0.199 & 1.294 \\
\hline SSB.SIZE & $\mathbf{0 . 0 1 2}$ & 1.708 & $\mathbf{0 . 0 9 0}$ & 2.113 \\
\hline B.SIZE & 0.001 & 0.308 & 0.758 & 2.389 \\
\hline B.MEET & $\mathbf{0 . 0 1 2}$ & 2.920 & $\mathbf{0 . 0 0 4}$ & 1.538 \\
\hline SSB.R & -0.039 & -1.333 & 0.184 & 3.042 \\
\hline SSB.CM & 0.045 & 1.178 & 0.241 & 3.222 \\
\hline AC.E & $\mathbf{0 . 0 8 9}$ & 2.176 & $\mathbf{0 . 0 3 1}$ & 4.480 \\
\hline AC.SIZE & $\mathbf{- 0 . 0 2 7}$ & -2.537 & $\mathbf{0 . 0 1 2}$ & 4.585 \\
\hline CAP & 0.000 & 0.764 & 0.446 & 1.638 \\
\hline LEV & 0.000 & 1.285 & 0.201 & 2.118 \\
\hline VOICE & -0.036 & -1.390 & 0.166 & 2.329 \\
\hline REGUL & -0.011 & -0.305 & 0.760 & 3.152 \\
\hline LAW & -0.118 & -2.031 & 0.044 & 5.052 \\
\hline CORR & -0.020 & -0.585 & 0.560 & 6.975 \\
\hline
\end{tabular}


Does the adoption of AAOIFI affect corporate social responsibility

Dr/ Mona AL Hakim \& Dr/ Sherif Al Halaby

\begin{tabular}{|c|c|}
\hline Year dummy & Included \\
\hline Country dummy & Included \\
\hline \multicolumn{2}{|l|}{ Model Summary } \\
\hline Adjusted R Square & 0.483 \\
\hline F value & 9.364 \\
\hline $\mathrm{P}$ value & 0.000 \\
\hline \multicolumn{2}{|c|}{$\begin{array}{l}\text { CSRD= Corporate Social Responsibility disclosure; SIZE= natural logarithm of total } \\
\text { assets; STAND= dummy code (standard) } 1 \text { if the banks adopt AAOIFI/other Islamic } \\
\text { standards or } 0 \text { otherwise; } \mathbf{L E V = ~ l e v e r a g e ~ r a t i o ~ b a s e d ~ o n ~ t o t a l ~ l i a b i l i t i e s ~ f o r ~ t o t a l ~ a s s e t s ; ~} \\
\text { ROA= profitability (return on assets); CAP= ratio of actual regulatory capital (Tier } 1 \\
\text { capital) to the minimum required regulatory capital; B.SIZE= total number board } \\
\text { members; B.MEET= number of BOD meeting within the year; SBB.SIZE= total } \\
\text { number of SSBM on the board; SSB.R= dummy code } 1 \text { if the SSBM are has } \\
\text { membership in a credible Islamic institutions as AAOIFI or } 0 \text { otherwise; SSB.CM= } \\
\text { dummy code } 1 \text { if SSB member with a cross membership in more than one Islamic bank } \\
\text { or } 0 \text { otherwise; AC.E= dummy code (audit committee exist) } 1 \text { if there is audit } \\
\text { Committee inside the Islamic banks or } 0 \text { otherwise; AC.SIZE= total number of audit } \\
\text { committee; The Worldwide Governance Indicators: VOICE= Voice and Accountability; } \\
\text { REGUL= Regulatory Quality; LAW= Rule of Law; CORR= Control of Corruption; } \\
\text { (*) Statistical significance at } 10 \% \text { level; (**) Statistical significance at } 5 \% \text { level; (***) } \\
\text { Statistical significance at } 1 \% \text { level }\end{array}$} \\
\hline
\end{tabular}

6. Summary and Conclusions

Adoption of accounting standards and CSR activities and its disclosure are areas which have seen significant growth in recent years. We studied the potential implications of the adoption of AAOIFI on the level of CSR disclosure that made by a sample of 36 Islamic across 6 GCC countries over the period 2010-2016. Our paper adopted a holistic index that included universal as well as Sharia oriented dimensions for CSR activities created from CSRD studies of Islamic banks and recommendations from 
Does the adoption of AAOIFI affect corporate social responsibility

Dr/ Mona AL Hakim \& Dr/ Sherif Al Halaby

AAOIFI Standard No.7. Our result showed a low disclosure level about CSR activities as an unexpected result. Based on the results presented in this study the following conclusion can be made. The empirical analysis highlighted a positive association between CSR disclosure index and banks' adoption of AAOIFI. This finding is matching with Hevas et al (2013); Oliver and Warsame (2016); Stecher \& Suijs (2012) about the implication of adoption financial accounting standards or the economic consequences of adoption accounting standards. Our finding also is matching with Smith et al (2014); Evans et al (2015) that investigated the implication of adoption accounting standards related to enhancing level of disclosure. The result supports the theoretical framework as adopting credit accounting standards encourages banks to engage more in social activities. This result is consistent with Emmanuel et al (2016) as they argued that adopting accounting standards lead to enhance level of disclosure. Interestingly, related to control variables we discovered a positive and significant association between the SSB size and CSRD index, which implies the essential role of the SSB in supporting Islamic banks social activities. The result is consistent with Farook et al (2011); Farag et al (2014) as they argued that larger SSB size may lead to higher levels of CSRD as the capacity of the monitoring role of the SSB increases. We also 
Does the adoption of AAOIFI affect corporate social responsibility

Dr/ Mona AL Hakim \& Dr/ Sherif Al Halaby

found a positive and significant association between the size; board meetings; audit committee existing and CSRD index.

The findings have a number of policy implications. Firstly, the empirical evidence indicates that the level of CSRD was relatively low (30\%) even though AAOIFI Standard has provided a template for Islamic banks to adopt in terms of CSR conduct and disclosure. Therefore, policymakers might, in future, be more active in encouraging Islamic banks to adopt AAOIFI Standard as a benchmark. Secondly, policy makers should be encouraged to ask IBs for adopting Islamic standards as AAOIFI. Adopting these standards enhances level of CSR which enhance the image of Islamic banks towards all stakeholders as well as firm value. Additionally, our empirical evidence suggested that an Islamic bank's involvement in CSR tends to increase as its SSB size grows larger. Therefore, policymakers should be encouraged to introduce policies to help increase the number of eligible SSB members as a larger SSB may encourage disclosure of the Islamic Bank's CSR and such disclosure provides evidence to the public that it is pursuing its social goals. Such policies might include more professional training programs which will help increase the supply of Sharia scholars. Also; this is the first study that explored CSRD and adoption AAOIFI in the context of the GCC countries, an economically important and culturally varied geographic context. The focus is significant in that it sheds light 
Does the adoption of AAOIFI affect corporate social responsibility

Dr/ Mona AL Hakim \& Dr/ Sherif Al Halaby

on the CSR-disclosing practices of IBs that operated in an environment that is often considered to be invariably opaque. This study may be extended in several ways. First, future research may explore the determinants on social activities by collecting data through detailed interviews with management and other stakeholders which might substantiate the findings from the CSRD studies. While there are many disclosure channels for CSRD (e.g., standalone corporate sustainability reports, company websites, press releases, and annual financial reports) (KPMG, 2008); the study uses only annual reports to measuring CSRD; thus asking for future researches that uses more than annual report to measure CSRD. Future research may explore other economic consequences for adoption AAOIFI as impacts on cost of capital; firm value and level of earning management. 
Does the adoption of AAOIFI affect corporate social responsibility

Dr/ Mona AL Hakim \& Dr/ Sherif Al Halaby

\section{References}

Abdul Rahman, A., Md Hashim, M.F.A., Abu Bakar, F., 2010. Corporate social reporting: a preliminary study of Bank Islam Malaysia Berhad (BIMB). Iss. Soc.Environ. Account. 4 (1), 18-39.

Abraham, S., Cox, P., 2007. Analyzing the determinants of narrative risk information in UK FTSE 100 annual reports. Brit. Account.Rev. 39, 227248.

Ahmad, K., 2000. Islamic finance and banking: challenges and prospects. Rev. Islam. Econom. 9, 57-82.

Alotaibi, K. O. and Hussainey, K. (2016), "Determinants of CSR disclosure quantity and quality: Evidence from non-financial listed firms in Saudi Arabia", International Journal of Disclosure and Governance, Vol. 13 No. 4, pp. 364-393.

Andres, D.P., Vallelado, E., 2008. Corporate governance in banking: the role of the board of directors. J. Bank. Finance 32, 2570-2580.

Anis, R., Fraser, I. and Hussainey, K. (2012), "A new measure for disclosure quality", Working paper, Stirling University.

Aribi, Z.A., Gao, S.S., 2012. Narrative disclosure of corporate social responsibility in Islamic financial institutions. Manage. Audit. J. 27 (2), 199-222.

Atwood, T. J., Drake, M. S., Myers, J. N., \& Myers, L. A. (2011). Do earnings reported under IFRS tell us more about future earnings and cash flows? Journal of Accounting and Public Policy, 30(2), 103-121.

Ball, R. (2006). International Financial Reporting Standards (IFRS): Pros and cons for investors. Accounting and Business Research, 36(Suppl. 1), 5-27.

Barth, M. E., Landsman, W. R., Lang, M., \& Williams, C. (2012). Are IFRSbased and US GAAP-based accounting amounts comparable? Journal of Accounting and Economics, 54, 68-93. 
Does the adoption of AAOIFI affect corporate social responsibility

Dr/ Mona AL Hakim \& Dr/ Sherif Al Halaby

Barth, M. E., Landsman, W. R., \& Lang, M. H. (2008). International Accounting Standards and accounting quality. Journal of Accounting Research, 46(3), 467-498.

Baydoun N, Willett R. Islamic corporate reports. ABACUS 2000;36(1):71-90.

Beattie, V., McInnes, W., Fearnley, S., 2004. A methodology for analysing and evaluating narratives in annual reports: a comprehensive descriptive profileand metrics for disclosure quality attributes. Account. Forum 28 (3), 205-236.

Belal, A.R., Abdelsalam, O., Nizamee, S., 2014. Ethical reporting in Islami Bank Bangladesh Limited (1983-2010). J. Bus. Ethics,http://dx.doi.org/10.1007/s10551-014-2133-8 (forthcoming).

Boesso, G., \& Kumar, K. (2007). Drivers of corporate voluntary disclosure: A framework and empirical evidence from Italy and the United States. Accounting Auditing and Accountability Journal, 20, 269-296.

Brammer, S., Brooks, C., Pavelin, S., 2006. Corporate social performance and stock returns: UK evidence from disaggregate measures. Financ. Manage.,97-116.Brammer, S., Millington:, A., 2006. Firm size, organizational visibility and corporate philanthropy: an empirical analysis'. Bus. Ethics: A Eur. Rev. 15 (1),6-18.

Barakat, F.S., Pérez, M.V.L. and Ariza, L.R. (2015), "Corporate social responsibility disclosure (CSRD) determinants of listed companies in Palestine (PXE) and Jordan (ASE)", Review of Managerial Science, Vol. 9 No. 4, pp. 681-702.

Branco, Manuel Castelo, \& Rodrigues, Lúcia Lima. (2008). Social responsibility disclosure: A study of proxies for the public visibility of Portuguese banks. The British Accounting Review, 40(2), 161-181.

Brown, P. (2011). International financial reporting standards: What are the benefits? Accounting and Business Research, 41(3), 269-285. 
Does the adoption of AAOIFI affect corporate social responsibility

Dr/ Mona AL Hakim \& Dr/ Sherif Al Halaby

Byard, D., Li, Y., \& Yu, Y. (2011). The effect of mandatory IFRS adoption on financial analysts' information environment. Journal of Accounting Research, 49(1), 69-96.

Chan, A. L., Hsu, A. W., \& Lee, E. (2013). Does mandatory IFRS adoption affect the credit ratings of foreign firms cross-listed in the US? Accounting Horizons, 27(3), 491-510.

Christensen, H. B. (2012). Why do firms rarely adopt IFRS voluntarily?

Academics find significant benefits and the costs appear to be low. Review of Accounting Studies, 17, 518-525.

Dahya, J., Lonie, A.A. and Power, D.M. (1996), "The case for separating the roles of chairman and CEO: an analysis of stock market and accounting data", Corporate Governance: An International Review, Vol. 4 No. 2, pp. 52-68.

Daske, H., Hail, L., Leuz, C., \& Verdi, R. (2013). Adopting a label:

Heterogeneity in the economic consequences around IAS/IFRS adoptions. Journal of Accounting Research, 51(3), 495-547.

Daske, H., Hail, L., Leuz, C., \& Verdi, R. (2008). Mandatory IFRS reporting around the world: Early evidence on the economic consequences. Journal of Accounting Research, 46(5), 1085-1142.

Daske, H., \& Gebhardt, G. (2006). International financial reporting standards and experts. Abacus, 42, 461-498.

Farook, S., 2008. Social responsibility for Islamic financial institutions: laying down a framework. J. Islam. Econ. Bank. Finance 4 (1), 61-82.

Farook, S., Hassan, M.K., Lanis, R., 2011. Determinants of corporate social responsibility: the case of Islamic banks. J. Islam. Account. Bus. Res. 2 (2), 114-141.

Gambling T, Karim RA. Islam and social accounting. Journal of Business \& Accounting 1986;13(1):39-50. 
Does the adoption of AAOIFI affect corporate social responsibility

Dr/ Mona AL Hakim \& Dr/ Sherif Al Halaby

Giannarakis, G. (2014a), "Corporate governance and financial characteristic effects on the extent of corporate social responsibility disclosure", Social Responsibility Journal, Vol. 10 No. 4, pp. 569-590.

Hail, L., Leuz, C., \& Wysocki, P. (2010). Global accounting convergence and the potential adoption of IFRS by the U.S. (Part I): Conceptual underpinnings and economics analysis. Accounting Horizons, 24(3), 355-394.

Hanefah, H. M. M., \& Singh, J. Convergence towards ifrs in malaysia: issues, challenges and opportunities. International Journal of Business, Economics and Law, Vol. 1, 43-47

Haniffa, R., Hudaib, M., 2007. Exploring the ethical identity of Islamic banks via communication in annual reports. J. Bus. Ethics 76, 97-116.

Haniffa, R. and Hudaib, M. (2004), "Disclosure practices of Islamic financial institutions:an exploratory study”, working paper series, School of Management, Bradford University, Bradford.

Haniffa, R., Cooke, T., 2002. Culture, corporate governance and disclosure in Malaysian corporations. $\quad$ Abacus 38, 349,http://dx.doi.org/10.1111/1467-6281.00112.

Harrison, J., \& Freeman, R. E. (1999). Stakeholders, social responsibility, and performance:Empirical evidence and theoretical perspectives. Academy of Management Journal, 42, 479-485.

Hassan, M.K., Imran, Y., Rashid, M. and Shahid, A.I. (2011), "Ethical gaps and market value in the Islamic banks of Bangladesh", Review of Islamic Economics (in press).

Hassan, A., Harahap, S.S., 2010. Exploring corporate social responsibility disclosure: the case of Islamic banks. Int. J. Islam. Middle E Finance Manage. 3 (3),203-227. 
Does the adoption of AAOIFI affect corporate social responsibility

Dr/ Mona AL Hakim \& Dr/ Sherif Al Halaby

Ho, S.S.M., Wong, K.S., 2001. A study of the relationship between corporate governance structures and the extent of voluntary disclosure. J. Int. Account.Audit. Tax. 10 (2), 139-156.

Houqe, N., van Kesteren, M., \& Clarkson, P. (2012a). Understanding IFRS adoption: A review of current debate and consequences. Working paper: Victoria University of Wellington.

Houqe, M. N., van Zijl, T., Dunstan, K., \& Karim, A. K. M. W. (2012b). The Effect of IFRS adoption and investor protection on earnings quality around the world. The International Journal of Accounting, 47(3), 333355.

Holthausen, R.W., 1990. Accounting method choice: opportunistic behavior, efficient contracting, and information perspectives.J. Account. Econ. 12 (1-3), 207-218.

Huang, L. Watson., 2015. Corporate social responsibility research in accounting Journal of Accounting Literature 34 (2015) 1-16.

Hussain, S.H. and Mallin, C. (2003), "The dynamics of corporate governance in Bahrain: structure, responsibilities and operation of corporate boards", Corporate Governance: An International Review, Vol. 11 No. 3, pp. 24962.

Iatridis, G., 2008. Accounting disclosure and corporations' financial attributes: evidence from the UK stock market. Int. Rev.Financ. Anal. 17 (2), 219 241.

Javaid Lone, E., Ali, A. and Khan, I. (2016), "Corporate governance and corporate social responsibility disclosure: evidence from Pakistan", Corporate Governance: The international journal of business in society, Vol. 16 No. 5, pp. 785-797. 
Does the adoption of AAOIFI affect corporate social responsibility

Dr/ Mona AL Hakim \& Dr/ Sherif Al Halaby

Jermakowicz, E.K., \& Gornik-Tomaszewski, S. (2006). Implementing IFRS from the perspective of EU publicly traded companies. Journal of International Accounting, Auditing and Taxation, 15, 170-196.

Kamla, R. (2009). Critical insights into contemporary Islamic accounting.Critical Perspectives on Accounting, 20(8), 921-932.

KPMG (2008). International survey of corporate responsibility reporting. http://us.kpmg.com/RutUS_prod/Documents/8/Corporate_Sustainability_ Report_US_Final.pd\&gt

Lambert, R., Leuz, C., \& Verrecchia, R. (2007). Accounting information, disclosure, and the cost of 3capital. Journal of Accounting Research, 45(2), 385-420.

Landsman\#, W. R., Maydew, E. L., \& Thornock, J. R. (2012). The information content of annual earnings announcements and mandatory adoption of IFRS. Journal of Accounting and Economics, 53(1-2), 34-54.

Leuz, C., Nanda, D., \& Wysocki, P. D. (2003). Earnings management and investor protection: An international comparison. Journal of Financial Economics, 69(3), 505-527.

Lewis MK. Islam and accounting. Accounting Forum 2001;25(June (2)):103-27.

Liao, Q., Sellhorn, T., \& Skaife, H. (2012). The cross-country comparability of IFRS earnings and book values: Evidence from France and Germany. Journal of International Accounting Research, 11(1), 155-184.

Li, S. (2010). Does mandatory adoption of International Financial Reporting Standards in the European Union reduce the cost of equity capital? The Accounting Review, 85(2), 607-636.

Linsley, P.M., Shrives, P.J., 2006. Risk reporting: a study of risk disclosure in the annual reports of UK companies. Brit. Account.Rev. 38 (1), 387-404. 
Does the adoption of AAOIFI affect corporate social responsibility

Dr/ Mona AL Hakim \& Dr/ Sherif Al Halaby

Lopes, P.T., \& Rodrigues, L.L. (2007). Accounting for financial instruments: An analysis of the determinants of disclosure in the Portuguese stock exchange. The International Journal of Accounting, 42, 25-56.

Maali, B., Casson, P., Napier, C., 2006. Social reporting by Islamic banks. Abacus 42 (2), 266-289.

Majeed, S., Aziz, T. and Saleem, S. (2015), "The Effect of Corporate

Governance Elements on Corporate Social Responsibility (CSR)

Disclosure: An Empirical Evidence from

Listed Companies at KSE Pakistan", International Journal of Financial Studies, Vol. 3 No. 4, pp. 530-556.

Mallin, C.A., Michelon, G., 2011. Board reputation attributes and corporate social performance: an empirical investigation of the US best corporate citizens.Account. Bus. Res. 41 (2), 119-144.

Maurer B. (2002) Anthropological and accounting knowledge in Islamic banking and finance: rethinking critical accounts. Journal of Royal Anthropological Institute, 8:645-67.

McVea, J.F., \& Freeman, R. (2005). A names-and-faces approach to stakeholder management:How focusing on stakeholders as individuals can bring ethics and entrepreneurial

strategy together. Journal of Management Inquiry, 14, 57-69.

Mohammed Sarea, A., \& Mohd Hanefah, M. (2013). The need of accounting standards for Islamic financial institutions: evidence from AAOIFI. Journal of Islamic Accounting and Business Research, 4(1), 64-76.

Muller, K., Riedl, E., \& Sellhorn, T. (2011). Mandatory fair value accounting and information asymmetry: Evidence from the European real estate industry. Management Science, 57(6), 1138-1153. 
Does the adoption of AAOIFI affect corporate social responsibility

Dr/ Mona AL Hakim \& Dr/ Sherif Al Halaby

Neu, D., Warsame, H. and Pedwell, K. (1998), "Managing Public Impressions:

Environmental Disclosures in Annual Reports", Accounting, Organizations and Society, Vol. 23 No. 3, pp. 265-282.

Oliveira, J.S., Rodrigues, L.L., Craig, R., 2011a. Voluntary risk reporting to enhance institutional and organizational legitimacy:evidence from Portuguese banks. J. Financ. Regul. Complian. 19 (3), 271-288.Oliveira, J.S., Rodrigues, L.L., Craig, R., 2011b. Risk-related disclosures by nonfinance companies: Portuguese practices anddisclosure characteristics. Manage. Audit. J. 26 (9), 817-839.

Pomeranz F. Ethics: toward globalization. Managerial Auditing Journal 2004;19(1):8-14.

Pope, P., \& McLeay, S. (2011). The European IFRS experiment: Objectives, research challenges and some early evidence. Accounting and Business Research, 41(3), 233-266.

Roberts, R.W., 1992. Determinants of corporate social responsibility disclosure. Account. Organ. Soc. 17 (6), 595-612.

Samaha, K., Dahawy, K., Hussainy, K., \& Stapleton, P. (2012). The extent of corporate governance disclosure and its determinants in a developing market: The case of Egypt. Advances in Accounting, incorporating Advances in International Accounting, 28(1),168-178.

Sarea, A. and Hanefah, M. (2013), "Adoption of AAOIFI accounting standards by Islamic banks of Bahrain”, Journal of Financial Reporting and Accounting, Vol. 11 No. 2, pp. 131-142.

Soderstrom, N., \& Sun, K. (2007). IFRS adoption and accounting quality: A review. The European Accounting Review, 16, 675-702.

Spence, C., \& Gray, R. (2007). Social and environmental reporting and the business case. Association of Chartered Certified Accountants (ACCA). Research report No. 98. 
Does the adoption of AAOIFI affect corporate social responsibility

Dr/ Mona AL Hakim \& Dr/ Sherif Al Halaby

Stecher, J., \& Suijs, J. (2012). Hail, Procrustes! Harmonized accounting standards as a procrustean bed. Journal of Accounting and Public Policy, 31(4), 341-355.

Sulaiman M, Willett $R$. Islam, economic rationalism and accounting. The American Journal of Islamic Social Sciences 2001;18(2).

Tayler, P. and Turley, S. (1986), "The Regulation of Accounting", Basil Block Well, Oxford. Ullah, M. (2013), "Compliance of AAOIFI guidelines in general presentation and disclosure in the financial statements of Islamic banks in Bangladesh", International Journal of Science Research, Vol. 1 No. 2, pp. 111-123.

van der Laan Smith, J., Adhikari, A., \& Tondkar, R.H. (2005). Exploring differences in social disclosures internationally: A stakeholder perspective. Journal of Accounting and Public Policy, 24, 123-151.

Vinnicombe, T. (2012), "A study of compliance with AAOIFI accounting standards by Islamic banks in Bahrain”, Journal of Islamic Accounting and Business Research, Vol. 3 No. 2, pp. 78-98. 